\title{
BMJ Open Polytobacco use and multiple-product smoking among a random community sample of African-American adults
}

\author{
Irma Corral, ${ }^{1}$ Hope Landrine ${ }^{2}$ Denise Adams Simms, ${ }^{3}$ Jukelia J Bess ${ }^{2}$
}

To cite: Corral I, Landrine $\mathrm{H}$, Simms DA, et al. Polytobacco use and multiple-product smoking among a random community sample of African-American adults. BMJ Open 2013;3:e003606. doi:10.1136/bmjopen-2013003606

- Prepublication history for this paper is available online. To view these files please visit the journal online (http://dx.doi.org/10.1136/ bmjopen-2013-003606).

Received 16 July 2013 Revised 31 October 2013 Accepted 1 November 2013

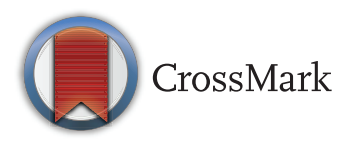

\footnotetext{
${ }^{1}$ Department of Psychiatric Medicine, Brody School of Medicine, East Carolina University, Greenville, North Carolina, USA

${ }^{2}$ Center for Health Disparities, East Carolina University, Greenville, North Carolina, USA

${ }^{3}$ California Black Health Network, San Diego, California, USA

Correspondence to Dr Hope Landrine; landrineh@ecu.edu
}

\section{ABSTRACT}

Objectives: Little is known about polytobacco use among African-American adults. This study is the first to explore this among a random, statewide, community sample of African-American adults.

Setting: Community-based sampling obtained a random, household-probability sample of AfricanAmerican adults from California, surveyed door to door in randomly selected census tracts statewide.

Participants: Participants were a statewide, randomhousehold sample of $\mathrm{N}=2118$ African-American adults from California who completed a survey on past 30-day smoking of cigarettes, blunts, bidis, kreteks, cigarillos, marijuana and cigars.

Results: Almost half (49.3\%) of the African-American cigarette-smokers and $14.9 \%$ of the cigarette nonsmokers had smoked at least one non-cigarette product in the past 30 days. Smokers had a substantial prevalence of smoking cigarillos (28.7\%) and blunts $(27.7 \%)$. Logistic regressions revealed that the odds of smoking most of the non-cigarette products were higher for cigarette smokers and men, inversely related to age, and unrelated to socioeconomic status.

However, smoking of blunts, bidis and kreteks was not predicted by cigarette smoking.

Conclusions: Smoking of cigarillos (eg, Phillies, Black \& Mild) and blunts may be prevalent among African-American cigarette-smokers and non-smokers alike, but such products are not examined in most population-level smoking research. Smoking of these products should be included in surveillance studies, in cancer prevention programmes and in healthcare provider-assessment of smoking, and addressed in smoking cessation programmes as well.

\section{INTRODUCTION}

Polytobacco use refers to the use of cigarettes in combination with another tobacco or smoked product such as cigars, kreteks (clove cigarettes), bidis (hand-rolled, flavoured tobacco wrapped in temburi or tendu leaves) and pipes. ${ }^{1-4}$ Compared to cigarette smoking, polytobacco use is associated with higher nicotine addiction, greater difficulty quitting tobacco and increased incidence of smoking-related cancers. ${ }^{1-5}$ These three

\section{Strengths and limitations of this study}

- A large random sample and high survey response rate.

- A sample from California whose results may not generalise elsewhere.

- Use of self-reports that may underestimate tobacco use.

outcomes are more prevalent among black than white smokers, ${ }^{5-7}$ even though AfricanAmericans smoke significantly fewer cigarettes per day and initiate smoking later in life ${ }^{5-7}$ Possible polytobacco use among African-Americans might be relevant to these puzzling tobacco-related racial disparities, and hence assessment of polytobacco use among African-American smokers is needed.

Population surveillance studies reveal that polytobacco use among adults is low, that is, $2.5 \%$ overall, $2.6 \%$ for white people, $2.9 \%$ for African-Americans. ${ }^{1}$ However, most population studies of adults, ${ }^{1}{ }^{3}$ unlike those of teens, ${ }^{48}$ did not assess smoking of bidis and kreteks. These products have 3-5 times higher nicotine, tar and carbon monoxide than conventional US cigarettes, ${ }^{9}{ }^{10}$ and the incidence of smoking-related cancers is up to $112 \%$ higher among bidi-smokers than among cigarette-smokers. ${ }^{11} 12$ The sole study of bidi smoking among a large, random sample of adults (ie, 18-24 year olds in the Behavioral Risk Factor Surveillance System) found that $25.4 \%$ of African-Americans had ever smoked bidis, a rate that was three times higher than that of white people. ${ }^{13}$ Likewise, a study of polytobacco use among military recruits found significantly higher use of bidis (but not of kreteks) among AfricanAmericans than white people. ${ }^{14}$

In addition to limited population data on African-American adult smoking of highly carcinogenic products such as bidis, population studies usually do not assess smoking of the products that are popular in the African- 
American community among cigarette-smokers and nonsmokers alike. Foremost among these are the thin, flavoured little cigars (ie, cigarillos ${ }^{15-17}$ ), such as Philly and Black $\mathcal{E}^{\circ}$ Mild that African-Americans often do not categorise as cigars, ${ }^{18}$ and blunts. ${ }^{15}$ The term blunts refers to two different products: Inexpensive, moderate-sized cigars (larger than cigarillos but smaller than standardsized cigars) that are wrapped in a single tobacco leaf and burn as fast as cigarettes, and moderate-sized cigars emptied of their tobacco, filled with marijuana and wrapped in a single tobacco leaf. Hence, irrespective of how the term is defined, blunts are tobacco products and have been analysed in tobacco studies. ${ }^{8}{ }^{15-17}$ Such studies found prevalence rates of up to $30 \%$ for both products among young African-American adults. ${ }^{8} 15-17$

Thus, little is known about African-American adult smoking of a variety of non-cigarette products. This study reports the first data on the prevalence and correlates of smoking blunts, cigarillos (Philly/Black $\mathcal{E}$ Mild by brand name), bidis, kreteks, standard-sized cigars and marijuana among a random, statewide, community sample of African-American adult smokers (polytobacco use) and non-smokers (multiple product smoking). Marijuana is not a tobacco product; it does not contain nicotine, and hence is generally excluded from studies of smoking. However, marijuana smoke contains many of the same carcinogens as cigarettes and is associated with increased cancer risk; hence, marijuana smoking may be relevant to understanding persistent, unexplained smoking-related cancer disparities among African-Americans. ${ }^{15}$

\section{METHOD}

\section{Procedures}

Participation in telephone and household interview health surveys is low among African-Americans (eg, $0.2-20 \%{ }^{19-21}$ ); hence, community-based sampling (CBS) and communitybased participatory research (CBPR) approaches were used to increase participation rates). ${ }^{22-24}$ CBS is a threestage, random-household probability sampling procedure often used in population studies of minorities to assure inclusion of segregated, linguistically isolated and phoneless/cell phone only households; hence, CBS yields more representative ethnic minority samples. ${ }^{23}{ }^{24}$ In CBS stage 1 , census data were used to identify the counties in which the majority of Californian African-Americans reside. This revealed that most $(90 \%)$ of the Californian AfricanAmerican population resides in seven counties, for example, Los Angeles (42\%), Sacramento (10\%), San Diego $(6 \%)$. African-Americans were sampled from these counties proportional to representation, that is, $42 \%$ of the sample came from Los Angeles county and 6\% from San Diego county (etc), such that this sample matched the distribution of the Californian African-American population. This was achieved by sampling more or fewer census tracts in each county as needed. ${ }^{24}$

In CBS stage 2, 513 census tracts (CTS) within the seven counties were randomly selected. In stage 3 , a smaller set of equal numbers of low-segregated (20-50\% of African-Americans) and high-segregated (60-92\% of African-Americans) CTS were randomly selected from the 513 tracts, and block groups within those randomly selected. Every household in the block groups was sampled door to door on weekends 2006-2008, with one adult participant permitted per household. The door to door method assured inclusion of phoneless/cell phone only households. Further details on the method are provided elsewhere. ${ }^{24}$ Because cigarette-smoking rates are significantly higher among phoneless/cell phone only households, ${ }^{19}$ their inclusion here via the door to door survey method is likely to yield higher smoking rates than are found in random telephone surveys.

The CBPR aspect of the study was cosponsorship by the California Black Health Network (CBHN), a well-known, trusted organisation that has conducted statewide tobacco assessment and tobacco-control programmes for Californian African-Americans since the 1970s. CBHN needed a statewide health assessment to improve its programmes and so cosponsored the study. CBHN staff (African-American adult surveyors) in each county collected the data in their counties. Surveyors wore CBHN ID badges, approached all households in the block groups, introduced themselves as CBHN staff and stated that the purpose of the survey was to acquire data needed to improve CBHN programmes in each black community. Surveyors handed potential participants an Informed Consent Letter that described the survey, stated the study purpose and included CBHN phone numbers (in each county) to call. Surveyors then asked if a black adult who resided in the household might wish to complete the anonymous California Black Health Network health survey for $\$ 10$ cash. Using these CBPR approaches, the response rate was $99 \%$-that is, of those who answered the door, $99 \%$ completed and only $1 \%$ refused the survey. ${ }^{24}$

Because up to $68 \%$ of cotinine-determined AfricanAmerican smokers deny smoking (self-report nonsmoking) in household interviews, ${ }^{25}$ a written survey was used instead. Anonymous written surveys decrease socially desirable denial of smoking and substance use and yield higher smoking and substance use prevalence rates ${ }^{26}$; hence, higher smoking rates are expected here than are found in random household surveys. Surveys were left with participants to complete in private and retrieved 30 minutes later. The study had the approval of the Institutional Review Board of San Diego State University.

\section{Materials/measures}

The survey assessed the health behaviours on which CBHN desired data (diet, physical activity, sun safety, smoking of a variety of products); only the smoking data are presented here. We explored past 30 day smoking (yes/no) of cigarettes, blunts, bidis, kreteks/clove cigarettes, two cigarillos by brand name (Philly, Black E Mild), standard-sized cigars and marijuana. Type of cigarettes smoked (menthol, nonmenthol, both) and demographic variables were also assessed. The survey took 15-30 minutes. 
Table 1 Prevalence of smoking non-cigarette products among a random sample of African-American adult cigarette smokers and non-smokers

\begin{tabular}{|c|c|c|c|c|}
\hline Past 30-day smoking of & Overall \% & Smokerst \% & Non-smokers $¥ \%$ & $\chi_{1}^{2 *}$ \\
\hline Philly; Black \& Mild & 13.0 & 28.7 & 5.3 & 176.389 \\
\hline Blunts & 14.1 & 27.7 & 7.5 & 23.255 \\
\hline Standard-sized cigars & 10.1 & 21.4 & 4.5 & 107.004 \\
\hline Marijuana & 18.6 & 33.0 & 11.4 & 113.856 \\
\hline Bidis & 2.0 & 5.0 & 0.5 & 35.97 \\
\hline Kreteks/cloves & 1.1 & 2.7 & 0.4 & 17.304 \\
\hline Any one or more of the above & 26.1 & 49.3 & 14.9 & 257.73 \\
\hline Men any one or more of the above & 33.6 & 57.3 & 19.5 & 114.803 \\
\hline Women any one or more of the above & 20.6 & 40.6 & 12.1 & 107.047 \\
\hline
\end{tabular}

\section{RESULTS}

Participants were a random, statewide sample of $\mathrm{N}=2118$, US-born, self-identified African-American adult residents of California, 1214 women $(57.3 \%)$ and 904 men $(42.7 \%)$, whose ages ranged from 18 to 95 years (mean=43.8, $\mathrm{SD}=16.2$ years). Details of their demographics have been presented elsewhere, ${ }^{24}$ and revealed that this 2006-2008 sample is similar to the 2006-2008 black population in the California Census. The prevalence of cigarette smoking among this sample was $32.6 \%$, and was significantly higher among men $(37.2 \%)$ than women $\left(29.7 \% ; \chi^{2}=10.651, \mathrm{p}<0.001\right)$.

Table 1 displays past 30-day smoking prevalence rates for six non-cigarette products among cigarette smokers and non-smokers. As shown, the prevalence of smoking one or more non-cigarette products was $49.3 \%$ for cigarette

\begin{tabular}{|c|c|c|c|c|c|}
\hline Model and variables entered & B & Wald & $\mathrm{p}$ Value & OR & $95 \% \mathrm{Cl}$ \\
\hline \multicolumn{6}{|l|}{ Step 1: Demographic variables } \\
\hline \multicolumn{6}{|l|}{ Age (years) } \\
\hline \multicolumn{6}{|l|}{45 and older (REF) } \\
\hline $18-24$ & 1.997 & 38.442 & 0.0005 & 7.37 & 3.919 to 13.856 \\
\hline $25-34$ & 1.05 & 17.546 & 0.0005 & 2.85 & 1.46 to 4.656 \\
\hline $35-44$ & 0.705 & 7.882 & 0.005 & 2.02 & 1.237 to 3.311 \\
\hline \multicolumn{6}{|l|}{ Gender } \\
\hline \multicolumn{6}{|l|}{ Women (REF) } \\
\hline Men & 0.931 & 22.023 & 0.0005 & 2.54 & 1.720 to 3.742 \\
\hline \multicolumn{6}{|l|}{ Education } \\
\hline \multicolumn{6}{|l|}{ Did not finish high school (REF) } \\
\hline High school graduate/GED & 0.051 & 0.022 & 0.882 & & \\
\hline College and higher & -0.227 & 1.078 & 0.299 & & \\
\hline \multicolumn{6}{|l|}{ Income } \\
\hline \multicolumn{6}{|l|}{ Less than $\$ 10999$ (REF) } \\
\hline$\$ 11000-\$ 25999$ & 0.330 & 1.156 & 0.282 & & \\
\hline$\$ 26000-\$ 49999$ & 0.524 & 3.445 & 0.063 & & \\
\hline$\$ 50000$ and higher & -0.189 & 0.437 & 0.508 & & \\
\hline \multicolumn{6}{|l|}{ Employment } \\
\hline \multicolumn{6}{|l|}{ Employed (REF) } \\
\hline Unemployed & 0.075 & 0.109 & 0.741 & & \\
\hline \multicolumn{6}{|l|}{ Step 2: Cigarette smoking } \\
\hline \multicolumn{6}{|l|}{ Smoking } \\
\hline \multicolumn{6}{|l|}{ Non-smoker (REF) } \\
\hline Smoker & 1.16 & 21.760 & 0.0005 & 3.19 & 1.962 to 5.212 \\
\hline \multicolumn{6}{|l|}{ Cigarette type } \\
\hline \multicolumn{6}{|l|}{ Non-Menthol (REF) } \\
\hline Menthol & 0.447 & 3.469 & 0.063 & & \\
\hline Both & 0.851 & 7.166 & 0.007 & 2.34 & 1.256 to 4.366 \\
\hline
\end{tabular}


smokers and $14.9 \%$ for non-smokers. Among AfricanAmerican men, the prevalence of smoking one or more non-cigarette products was $57.3 \%$ for smokers and $19.5 \%$ for non-smokers; among women, these rates were $40.6 \%$ (cigarette smokers) and $12.1 \%$ (non-smokers).

Table 2 displays the hierarchical logistic regression predicting smoking of any non-cigarette product from demographic and cigarette-smoking variables. As shown, smoking non-cigarette products was predicted by age, gender and cigarette smoking but not by socioeconomic status (SES; education, income, employment). Men $(\mathrm{OR}=2.5)$, cigarette smokers $(\mathrm{OR}=3.2)$ and young adults $(\mathrm{OR}=7.4)$ were more likely to smoke non-cigarette products, and the odds of smoking the products increased with decreasing age.

Table 3 displays separate regressions predicting smoking of blunts and of the cigarillos Philly/Black $\mathcal{E}^{2}$ Mild. Age, gender and higher incomes were predictors of smoking blunts. The odds of smoking blunts were 2.5 times higher for men, and increased as age decreased, with young (ages 18-24) adults being 6.3 times more likely than older ones (ages 45 and older) to smoke blunts. Philly/Black $\mathcal{E}^{2}$ Mild smoking was predicted by age, gender and cigarette smoking. Men were 2.6 times more likely than women, young adults 15.9 times more likely than older ones and cigarette smokers 5.3 times more likely than non-smokers to smoke Philly/Black and Mild.

The separate regressions predicting cigar-smoking and marijuana-smoking (table 4) found age, gender and cigarette smoking to be predictors of both. Men, young adults and smokers were 2.5-3 times more likely to smoke standard-sized cigars than their reference groups. For marijuana-smoking, men were twice as likely, the youngest age group six times more likely, and smokers 2.5 times more likely than their reference groups to smoke marijuana. A similar regression predicting bidi-smoking (table 5) revealed that age was the sole predictor, with those aged 18-24 (OR=4.7) and 35-44 (OR 4.4) years old being more likely to smoke bidis than the older age group. The regression predicting smoking kreteks/cloves (table 5) revealed that age and smoking menthol cigarettes were the predictors; those aged 35-44 were 11 times more likely, and menthol smokers $(\mathrm{OR}=0.205)$ were less likely to smoke kreteks/cloves.

Table 3 Logistic regressions predicting African-American adult smoking of Blunts and of Philly/Black \& Mild cigarillos

\begin{tabular}{|c|c|c|c|c|c|c|c|c|}
\hline \multirow[b]{2}{*}{ Variables entered } & \multicolumn{4}{|l|}{ Blunts } & \multicolumn{4}{|c|}{ PhillylBlack \& Mild cigarillos } \\
\hline & $\overline{\text { Wald }}$ & p Value & OR & $95 \% \mathrm{Cl}$ & Wald & p Value & OR & $95 \% \mathrm{CI}$ \\
\hline \multicolumn{9}{|l|}{ Step 1: Demographics } \\
\hline \multicolumn{9}{|l|}{ Age (years) } \\
\hline \multicolumn{9}{|l|}{45 and older (REF) } \\
\hline $18-24$ & 29.69 & 0.0005 & 6.25 & 3.23 to 12.08 & 51.69 & 0.0005 & 15.90 & 7.48 to 33.81 \\
\hline $25-34$ & 13.31 & 0.0005 & 3.07 & 1.68 to 5.62 & 21.33 & 0.0005 & 4.23 & 2.29 to 7.80 \\
\hline $35-44$ & 7.208 & 0.007 & 2.38 & 1.26 to 4.48 & 14.22 & 0.0005 & 3.38 & 1.79 to 6.36 \\
\hline \multicolumn{9}{|l|}{ Gender } \\
\hline \multicolumn{9}{|l|}{ Women (REF) } \\
\hline Men & 14.10 & 0.0005 & 2.49 & 1.55 to 4.02 & 14.02 & 0.0005 & 2.57 & 1.57 to 4.21 \\
\hline \multicolumn{9}{|l|}{ Education } \\
\hline \multicolumn{9}{|c|}{ Not high school graduate (REF) } \\
\hline High school graduate/GED & 0.82 & 0.365 & & & 0.928 & 0.335 & & \\
\hline College and higher & 1.066 & 0.302 & & & 0.616 & 0.433 & & \\
\hline \multicolumn{9}{|l|}{ Income } \\
\hline \multicolumn{9}{|l|}{ Less than $\$ 10999$ (REF) } \\
\hline$\$ 11000-\$ 25999$ & 3.925 & 0.048 & 2.17 & 1.01 to 4.66 & 0.375 & 0.540 & & \\
\hline$\$ 26000-\$ 49999$ & 4.792 & 0.029 & 2.18 & 1.09 to 4.37 & 0.289 & 0.591 & & \\
\hline$\$ 50000$ and higher & 0.051 & 0.821 & & & 0.089 & 0.766 & & \\
\hline \multicolumn{9}{|l|}{ Employment } \\
\hline \multicolumn{9}{|l|}{ Employed (REF) } \\
\hline Unemployed & 0.259 & 0.611 & & & 1.29 & 0.257 & & \\
\hline \multicolumn{9}{|l|}{ Step 2: Cigarette smoking } \\
\hline \multicolumn{9}{|l|}{ Smoking } \\
\hline \multicolumn{9}{|l|}{ Non-smoker (REF) } \\
\hline Smoker & 3.767 & 0.052 & 1.89 & 0.994 to $3.59^{\star}$ & 19.75 & 0.0005 & 5.34 & 2.55 to 11.18 \\
\hline \multicolumn{9}{|l|}{ Type } \\
\hline \multicolumn{9}{|l|}{ Non-menthol (REF) } \\
\hline Menthol & 0.521 & 0.470 & & & 6.72 & 0.013 & 2.36 & 1.19 to 4.66 \\
\hline Both & 0.169 & 0.681 & & & 15.42 & 0.005 & 5.08 & 2.26 to 11.43 \\
\hline
\end{tabular}


Table 4 Logistic regressions predicting African-American adult smoking of cigars and of marijuana

\begin{tabular}{|c|c|c|c|c|c|c|c|c|}
\hline \multirow[b]{2}{*}{ Variables entered } & \multicolumn{4}{|c|}{ Standard-sized cigars } & \multicolumn{4}{|c|}{ Marijuana } \\
\hline & Wald & p Value & OR & $95 \% \mathrm{Cl}$ & Wald & p Value & OR & $95 \% \mathrm{Cl}$ \\
\hline \multicolumn{9}{|l|}{ Step 1: Demographics } \\
\hline \multicolumn{9}{|l|}{ Age (years) } \\
\hline \multicolumn{9}{|l|}{45 and older (REF) } \\
\hline $18-24$ & 9.023 & 0.003 & 2.99 & 1.46 to 6.09 & 30.68 & 0.0005 & 6.05 & 3.20 to 11.45 \\
\hline $25-34$ & 0.819 & 0.365 & & & 25.30 & 0.0005 & 4.13 & 2.38 to 7.17 \\
\hline $35-44$ & 4.132 & 0.042 & 1.98 & 1.03 to 3.82 & 6.85 & 0.009 & 2.18 & 1.22 to 3.90 \\
\hline \multicolumn{9}{|l|}{ Gender } \\
\hline \multicolumn{9}{|l|}{ Women (REF) } \\
\hline Men & 16.823 & 0.0005 & 3.08 & 1.80 to 5.28 & 11.51 & 0.001 & 2.14 & 1.38 to 3.32 \\
\hline \multicolumn{9}{|l|}{ Education } \\
\hline \multicolumn{9}{|c|}{ Not high school graduate (REF) } \\
\hline High school graduate/GED & 0.264 & 0.607 & & & 1.03 & 0.310 & & \\
\hline College and higher & 0.004 & 0.947 & & & 0.129 & 0.719 & & \\
\hline \multicolumn{9}{|l|}{ Income } \\
\hline \multicolumn{9}{|l|}{ Less than $\$ 10999$ (REF) } \\
\hline$\$ 11000-\$ 25999$ & 0.518 & 0.472 & & & 1.35 & 0.245 & & \\
\hline$\$ 26000-\$ 49999$ & 2.065 & 0.151 & & & 2.14 & 0.143 & & \\
\hline$\$ 50000$ and higher & 0.473 & 0.492 & & & 0.048 & 0.826 & & \\
\hline \multicolumn{9}{|l|}{ Employment } \\
\hline \multicolumn{9}{|l|}{ Employed (REF) } \\
\hline Unemployed & 0.032 & 0.858 & & & 1.08 & 0.300 & & \\
\hline \multicolumn{9}{|l|}{ Step 2: Cigarette smoking } \\
\hline \multicolumn{9}{|l|}{ Smoking } \\
\hline \multicolumn{9}{|l|}{ Non-smoker (REF) } \\
\hline Smoker & 6.305 & 0.012 & 2.54 & 1.23 to 5.26 & 9.42 & 0.002 & 2.55 & 1.40 to 4.64 \\
\hline \multicolumn{9}{|l|}{ Type } \\
\hline \multicolumn{9}{|l|}{ Non-menthol (REF) } \\
\hline Menthol & 0.162 & 0.687 & & & 3.83 & 0.050 & 1.76 & 0.999 to $3.09^{*}$ \\
\hline Both & 1.887 & 0.170 & & & 2.74 & 0.098 & & \\
\hline
\end{tabular}

\section{DISCUSSION}

There was a high $(49.3 \%)$ prevalence of polytobacco use among African-American adult cigarette smokers that held for men $(57.3 \%)$ and women $(40.6 \%)$. Substantial smoking of non-cigarette products was also found among non-cigarette smokers, with $19.5 \%$ of men and $12.1 \%$ of women non-smokers smoking at least one noncigarette product in the past 30 days. The odds of smoking most non-cigarette products were generally higher for men than women (ORs=2.5 to 3.0), and for cigarette smokers than non-smokers $(\mathrm{ORs}=3.2$ to 5.3); however, gender did not contribute to smoking bidis or kreteks, and cigarette smoking did not contribute to smoking bidis, kreteks or blunts. Smoking of any noncigarette product and of each specific product was generally highest among adults aged 18-24 years (ORs=3 to $15.9)$ as in prior studies, ${ }^{13-16}$ and decreased as age increased. The exception was smoking kreteks/cloves; for these, older adults were more likely to be users. Moreover, unlike the well-known relationship between cigarette smoking and low SES, ${ }^{1}{ }^{3-5}$ for these noncigarette products, SES was related only to smoking blunts, with higher incomes a predictor. The type of cigarette smoked contributed to smoking non-cigarette products in general, and to smoking Phillies/Blacks specifically, with higher odds for those who smoked menthol and non-menthol cigarettes, rather than one or the other; menthol smoking generally did not predict the use of other products.

These findings suggest a problematically high prevalence of polytobacco use among African-American smokers that is strongly associated with gender and young adulthood but not associated with low income, low education or menthol smoking. Polytobacco users were mostly young men of varied SES who smoked all types of cigarettes along with non-cigarette productsthat is, a possible pattern of smoking whatever was available. Given that low SES was not a risk factor for this, polytobacco use might perhaps instead be related to the social risk factors for cigarette smoking among AfricanAmericans that have been identified in prior studiesthat is, racial segregation ${ }^{27-29}$ and racial discrimination. ${ }^{30-32}$ High levels of residential segregation (with high exposure to targeted tobacco advertising and easy access to single cigarettes in black neighbourhoods), and high levels of (the stress of) racial discrimination 
Table 5 Logistic regressions predicting African-American adult smoking of bidis and of kreteks/cloves

\begin{tabular}{|c|c|c|c|c|c|c|c|c|}
\hline \multirow[b]{2}{*}{ Variables entered } & \multicolumn{4}{|l|}{ Bidis } & \multicolumn{4}{|c|}{ Kreteks/clove cigarettes } \\
\hline & Wald & p Value & OR & $95 \% \mathrm{Cl}$ & Wald & p Value & OR & $95 \% \mathrm{Cl}$ \\
\hline \multicolumn{9}{|l|}{ Step 1: Demographics } \\
\hline \multicolumn{9}{|l|}{ Age (years) } \\
\hline \multicolumn{9}{|l|}{45 and older (REF) } \\
\hline $18-24$ & 4.634 & 0.031 & 4.74 & 1.15 to 19.55 & 0.000 & 0.997 & & \\
\hline 25-34 & 3.256 & 0.071 & & & 3.540 & 0.06 & 5.79 & 0.929 to $36.04^{\star}$ \\
\hline $35-44$ & 5.000 & 0.025 & 4.43 & 1.20 to 16.32 & 7.265 & 0.007 & 11.09 & 1.928 to 63.79 \\
\hline \multicolumn{9}{|l|}{ Gender } \\
\hline \multicolumn{9}{|l|}{ Women (REF) } \\
\hline \multirow{2}{*}{\multicolumn{9}{|c|}{ Education }} \\
\hline & & & & & & & & \\
\hline \multicolumn{9}{|c|}{ Not high school graduate (REF) } \\
\hline High school graduate/GED & 0.000 & 0.990 & & & 0.033 & 0.855 & & \\
\hline College and higher & 0.013 & 0.910 & & & 1.447 & 0.229 & & \\
\hline \multicolumn{9}{|l|}{ Income } \\
\hline \multicolumn{9}{|l|}{ Less than $\$ 10999$ (REF) } \\
\hline$\$ 11000-\$ 25999$ & 1.044 & 0.307 & & & 0.758 & 0.384 & & \\
\hline$\$ 26000-\$ 49999$ & 0.119 & 0.731 & & & 0.812 & 0.367 & & \\
\hline$\$ 50000$ and higher & 0.089 & 0.776 & & & 0.229 & 0.632 & & \\
\hline \multicolumn{9}{|l|}{ Employment } \\
\hline \multicolumn{9}{|l|}{ Employed (REF) } \\
\hline Unemployed & 1.719 & 0.190 & & & 0.116 & 0.734 & & \\
\hline \multicolumn{9}{|l|}{ Step 2: Cigarette smoking } \\
\hline \multicolumn{9}{|l|}{ Smoking } \\
\hline \multicolumn{9}{|l|}{ Non-smoker (REF) } \\
\hline Smoker & 2.126 & 0.145 & & & 0.000 & 0.996 & & \\
\hline \multicolumn{9}{|l|}{ Type } \\
\hline \multicolumn{9}{|l|}{ Non-menthol (REF) } \\
\hline Menthol & 0.753 & 0.386 & & & 4.365 & 0.037 & 0.205 & 0.046 to 0.907 \\
\hline Both & 2.341 & 0.126 & & & 0.488 & 0.485 & & \\
\hline
\end{tabular}

might be associated with smoking any cigarette and noncigarette product available. Studies of the possible role of these factors in polytobacco use among AfricanAmericans are needed.

The $14.9 \%$ prevalence of the past 30-day smoking of non-cigarette products by non-cigarette smokers also is a concern. Smoking blunts and bidis was not associated with cigarette smoking but was strongly associated with youth. This suggests that smoking blunts and bidis might reflect youthful experimentation, ${ }^{13} 1517$ and raises questions about whether young African-Americans try these before they try cigarettes. ${ }^{13}$ Studies of age of initiating smoking of cigarettes versus blunts and cigarillos among African-Americans are needed to clarify this.

This study also found a substantial prevalence of smoking products that are not assessed in most population smoking surveys of adults (eg, marijuana, cigarillos, blunts). Hence, it would be beneficial for surveillance studies to assess smoking of blunts, bidis and (in particular) cigarillos such as Phillies, Black E Mild and Swisher Sweets. Smoking of cigarillos may need to be assessed by brand name because young African-Americans often do not categorise them as cigars, ${ }^{18}$ and hence their reports of cigar use increase significantly when these brand names are included. ${ }^{18}$ That these cigarillos are sold individually and come in a variety of flavours (eg, chocolate, apple, cherry) may contribute to their not being categorised as cigars or as cigarettes. Such an assessment will provide a more comprehensive picture of smoking among African-American adults, and would match the complexity of recent (2011) assessments of youth smoking that included bidis, kreteks and cigarillos. ${ }^{33}$

This study has several limitations, including the use of self-reports that may be lower than biologically validated data, ${ }^{25}$ lack of assessment of some forms of tobacco use (eg, pipes) and a Californian sample whose data might not generalise to other states. In addition, we treated age as a categorical variable rather than as a continuous variable, and this may have limited the sensitivity of analyses. We note, however, that the age categories used here are similar to those used in prior studies of polytobacco use in which the highest prevalence found was for 18-24 year olds. ${ }^{13-16}$ Moreover, to decrease the number of consecutive significance tests, potentially interesting interaction effects (eg, gender $\times$ age, gender $\times$ income) were not examined; such effects, however, are generally 
not examined in basic epidemiological studies of product use (33), and this is a limitation of this study and of similar studies. Likewise, because more than $90 \%$ of these African-American cigarette-smokers consumed 10 or fewer cigarettes per day, the potential relationships between the number of cigarettes smoked and smoking of other products were not examined. In addition, the prevalence of smoking the products may have changed since this study. This is particularly the case for kreteks (clove cigarettes) that were banned by the 2009 Family Smoking Prevention and Tobacco Control Act. ${ }^{34}$ The Center for Disease Control's 2011 study of youth ${ }^{33}$ revealed that youth still smoke kreteks despite the ban, and this suggests that adults also might still smoke them. How youth and adults acquire banned and illegal products is worthy of investigation.

Despite these limitations, this study is the first to highlight the magnitude and complexity of smoking among a random community sample of African-American adults, and the first to underscore the need to improve its assessment in research and practice. More comprehensive, population-level assessment of multiplesubstance smoking might yield data that in part explain African-American smokers' difficulty in quitting tobacco despite smoking only a few cigarettes per day ${ }^{5}$ and likewise might yield findings that in part explain the puzzling high incidence of smoking-related cancers at young ages among African-American men. ${ }^{7} 35$ Similarly, it would be beneficial for healthcare providers to include non-cigarette products such as bidis and blunts in 5A (ask, advise, assess, assist and arrange) assessment of smoking $^{36}$ among cigarette smokers and non-smokers alike, young adults in particular. Smoking cessation interventions also might be enhanced by assessing and addressing cessation of smoking such products. However, whether evidence-based smoking cessation interventions and nicotine replacement therapy are effective with polytobacco users remain unknown. Studies are needed to assess the possibility that hidden polytobacco use might contribute to the relative failure of standard smoking cessation programmes with black smokers, ${ }^{5} 6$ and research on the possible need for new cessation interventions for polytobacco users is needed as well.

Contributors IC, HL, JB and DAS have made substantial contributions to study conception and design, acquisition of data, and analysis and interpretation of data, drafting the article or revising it critically for important intellectual content and gave final approval for the final version of the manuscript to be published.

Funding Supported by Tobacco-Related Disease Research Program Grant No. 15AT-1300.

\section{Competing interests None.}

Ethics approval Institutional Review Board, San Diego State University.

Provenance and peer review Not commissioned; externally peer reviewed.

Data sharing statement No additional data are available.

Open Access This is an Open Access article distributed in accordance with the Creative Commons Attribution Non Commercial (CC BY-NC 3.0) license, which permits others to distribute, remix, adapt, build upon this work noncommercially, and license their derivative works on different terms, provided the original work is properly cited and the use is non-commercial. See: http:// creativecommons.org/licenses/by-nc/3.0/

\section{REFERENCES}

1. Centers for Disease Control and Prevention. Any tobacco use in 13 states Behavioral Risk Factor Surveillance System, 2008. MMWR Morb Mortal Wkly Rep 2010;59:946-50.

2. Bombard JM, Pederson LL, Nelson DE, et al. Are smokers only using cigarettes? Addict Behav 2007;32:2411-19.

3. King BA, Dube SR, Tynan MA. Current tobacco use among adults in the United States: findings from the National Adult Tobacco Survey. Am J Public Health 2012;102:e99-100.

4. Centers for Disease Control and Prevention. Tobacco use among middle and high school students United States, 2000-2009. MMWR Morb Mortal Wkly Rep 2010;59:1063-8.

5. Fagan P, Moolchan ER, Lawrence D, et al. Identifying health disparities across the tobacco continuum. Addiction 2007; 102(Suppl 2):5-29.

6. Trinidad DR, Pérez-Stable EJ, White MM, et al. A nationwide analysis of US racial/ethnic disparities in smoking behaviors, smoking cessation, and cessation-related factors. Am J Public Health 2011;101:699-706.

7. Haiman CA, Stram DO, Wilkens LR, et al. Ethnic and racial differences in smoking-related risk of lung cancer. New Eng J Med. 2006;354:333-42.

8. Delneveo CD, Hrywna M. The relationship of cigars, marijuana, and blunts to adolescent bidi use. Public Health Rep 2006; 121:603-8.

9. Malson JL, Lee EM, Murty R, et al. Clove cigarette smoking: biochemical, physiological, and subjective effects. Pharm Biochem Behav 2003;74:739-45.

10. Watson $\mathrm{CH}$, Polzin $\mathrm{GM}$, Calafat $\mathrm{AM}$, et al. Determination of the tar, nicotine, and carbon monoxide yields in the smoke of bidi cigarettes. Nicotine Tob Res 2003;5:747-53.

11. Ganesh B, Sushama S, Monika S, et al. A case-control study of risk factors of lung cancer in Mumbai, India. Asian Pac J Cancer Prev 2011;12:357-62.

12. Jayalekshmi PA, Gangadharan $P$, Akiba $S$, et al. Oral cavity cancer risk in relation to tobacco chewing and bidi smoking among men in Karunagappally, Kerala, India. Cancer Sci 2011;102:460-7.

13. Delnevo CD, Pevzner ES, Myrwna M, et al. Bidi cigarette use among young adults in 15 states. Prev Med 2004;39:207-11.

14. Vander Weg MW, Peterson AL, Ebbert JO, et al. Prevalence of alternative forms of tobacco use in a population of young adult military recruits. Addict Behav 2008;33:69-82.

15. Sinclair CF, Foushee HR, Pevear JS, et al. Patterns of blunt use among young adult African-American men. Am J Prev Med 2012;42:61-4

16. Jolly $\mathrm{DH}$. Exploring the use of little cigars by students at a historically Black university. Prev Chronic Dis 2008;5:3-11.

17. Page JB, Evans S. Cigars, cigarillos and youth: Emerging patterns and subcultural complexities. J Ethn Subst Abuse 2003;2:63-76.

18. Yerger VB, Pearson C, Malone R. When is a cigar not a cigar? Am J Public Health 2001;91:316-17.

19. Blumberg SJ, Luke JV, Cynamon ML. Telephone coverage and health survey estimates: evaluating the need for concern about wireless substitution. Am J Public Health 2006;96:926-31.

20. Link MW, Mokdad AH, Stackhouse HF, et al. Race, ethnicity, and linguistic isolation as determinants of participation in public health surveillance surveys. Prev Chronic Dis 2006;3:1-12.

21. Satia JA, Galanko JA, Rimer BK. Methods and strategies to recruit African-Americans into cancer prevention surveillance studies. Cancer Epidemol Bio Prev 2005;14:718-21.

22. Carroll JK, Yancey AK, Spring B, et al. What are successful recruitment and retention strategies for underserved populations? Translational Behav Med 2011;234-51.

23. Cabral DN, Napoles-Springer AM, Miike R, et al. Population- and community-based recruitment of African Americans and Latinos. Am J Epidemiol 2003;158:272-9.

24. Pichon LC, Corral I, Landrine $\mathrm{H}$, et al. Sun protection behaviors among African-Americans. Am J Prev Med 2010;38:288-95.

25. Fisher MA, Taylor GW, Shelton BJ, et al. Age and race/ ethnicity-gender predictors of denying smoking, United States. $J$ Health Care Poor Underserv 2008;19:75-89.

26. Beebe TJ, McRae JA, Harrison PA, et al. Mail surveys result in more reports of substance use. J Clin Epidemiol 2005;58:421-4. 
27. Liao Y, Tucker P, Okoro CA, et al. REACH 2010 Surveillance for health status in minority communities. MMWR Surveill Summ 2004;53:1-36.

28. Landrine $\mathrm{H}$, Klonoff EA. Racial segregation and cigarette smoking among Blacks. J Health Psych 2000;5:211-19.

29. Datta GD, Subramanian SV, Colditz GA, et al. Individual, neighborhood, and state-level predictors of smoking among US Black women. Soc Sci Med 2006;63:1034-44.

30. Borrell LN, Diez Roux AV, Jacobs DR, et al. Perceived racial/ethnic discrimination, smoking, and alcohol consumption in the Multi-Ethnic Study of Atherosclerosis (MESA). Prev Med 2010;51:307-12.

31. Shariff-Marco S, Klassen AC, Bowie JV. Racial/ethnic differences in self-reported racism and its association with cancer-related health behaviors. Am J Public Health 2010;100:364-74.
32. Corral I, Landrine H. Racial discrimination and health-promoting vs. damaging behaviors among African-American adults. $J$ Health Psych 2012;17:1176-82.

33. Centers for Disease Control and Prevention. Tobacco use among middle and high school students United States, 2011. MMWR Morb Mortal Wkly Rep 2012;61:581-5.

34. See http://www.fda.gov/TobaccoProducts/GuidanceCompliance RegulatoryInformation

35. Elk R, Landrine H. Cancer disparities. New York, NY: Springer, 2012.

36. Weglicki LS. Tobacco use assessment: what exactly is your patient using and why is it important to know? Ethn Dis 2008;18(3 Suppl 3): S3-6. 